\title{
Analysis Of Raw Water Supply In Pucang Gading Housing Complex, District of Demak To Preparation Of Water Resources And Water Resources Management
}

\author{
Solikhul Abdi ${ }^{1}$, Sudarno $^{2}$ \\ ${ }^{1}$ Magister Program of Environmental Science, School of Postgraduate Studies, Diponegoro University, Semarang - Indonesia \\ ${ }^{2}$ Department of Environmental Engineering, Faculty of Engineering, Diponegoro University, Semarang - Indonesia
}

\begin{abstract}
Pucang Gading Housing Complex is an area within the Village Batursari, District of Demak with a population of 2018 as many as 44,257 inhabitants.

Raw water service system Mranggen Unit is divided into 5 areas of service (service area Mranggen, Batursari I, Batursari II, Batursari III and Kebon) which utilize raw water source of water treatment plant (IPA Waru) and 8 Wells In a total discharge of 120 liter/second.

The number of home connections in Pucang Gading area is currently 3,374 house connections, with a total water usage 14.25 liter/second Water discharges from clean water sources in Pucang Gading region are currently not maximally available to supply water to Pucang Gading service area. In this research will know the problems and readiness that exist by looking from the achievement of Medium Term Development Plan of Demak Regency Year 2016-2021. This research uses SWOT analysis method that is internal and external factors.

The selection of raw water sources for drinking water should pay attention to aspects of quality, quantity and continuity. Demak Regency has the potential of surface water either river/ reservoir/dam.

The problems and challenges of drinking water supply include issues of safe access to water supply, and regulation of groundwater utilization for the community.
\end{abstract}

Keywords : raw water supply, SWOT analysis, government policy, water resources management

\section{Introduction}

Mranggen Sub-district is one of the sub-districts in Demak District. In the north it is adjacent to Sayung Subdistrict, Regency of Karangawen in the east, Regency of Semarang in the south and Regency of Semarang in the west. The farthest distance from west to east is $5 \mathrm{~km}$ long and from north to south along $29 \mathrm{~km}$. Distance to the Capital of Demak $29 \mathrm{~km}$, while the distance to the district around is to District Karangawen $7 \mathrm{~km}$ and to District Sayung $12 \mathrm{~km}$.

The condition of clean water production in drinking water supply in Pucang Gading area of Mranggen district of Demak Regency is $77.61 \%$. This shows that in Pucang Gading service, the water loss rate is quite high, because it exceeds the maximum allowable water loss rate of 20\% (General Cipta Karya Dinas PU). While the level of water loss in the distribution pipe is $20.71 \%$.

he current condition of drinking water supply in Indonesia is that access to safe drinking water is only $67.7 \%$ consisting of $17.9 \%$ pipeline network instead of $49.8 \%$ pipeline network. For the drinking water service Provincial Government of Central Java for urban areas amounted to $72.48 \%$ while for rural areas reached $65.57 \%$. Referring to the policy of drinking water provision in Indonesia with the goal of meeting the needs of drinking water adequately that meet health requirements, the targets mandated in the National Medium-Term Development Plan 2015-2019 namely the achievement of $100 \%$ secure access to drinking water in 2019 , consisting from drinking water service through piped network (JP) of $60 \%$ or 27.7 Million house connections, and through non-piped network (BJP) protected by $40 \%$ or 1.9 Million Household. In order to achieve $100 \%$ safe and sustainable drinking water access target in 2019, the Directorate of Development of Drinking Water Supply System proclaimed the 10 million house connections program which is the target of adding 3\% per year pipeline access network or 2 million house connections per year, with the total addition of house connections to with 2019 of 10 million house connections.

One of the mandates of Law Number 23 of 2014 on Regional Government is that the regions have the right to enact local policies to administer the Government affairs which are the regional authorities. Through Government Regulation No. 2 of 2015 on RPJM that the target and target of drinking water is $100 \%$ appropriate in 2019. In order to achieve the mandate of the legislation in question is required preparation of study of drinking water needs in Central Java Province.

Based on Drinking Water Supply System (SPAM) Existing condition of Pucang Gading and in the 
framework of projection of raw water requirement for drinking water until 2030, the government tries to make improvements to SPAM eksisiting conditions in the areas and to identify raw water sources that can be utilized to fulfill drinking water service up to 2030 and identify a list of alternative water locations for drinking water. The Study of Raw Water Needs for Drinking Water is a reference document of regional planning in solving the problems and challenges of SPAM implementation. Problems and challenges of the regions to be addressed include the issue of safe access to drinking water, the issue of meeting the needs of raw water for drinking water, the issue of alternative sources of raw water for drinking water that can be utilized.

\section{Problems}

1) Availability of raw water resources potential in Mranggen district, Demak regency.

2) Community-based and non-supervised water utilization, due to unclear installation of piping and water supply in Pucang Gading housing complex.

3) How far the achievement of targets of the Medium Term Development Plan of Demak Regency Year 2016-2021 against the fulfillment of water needs.

4) The occurrence of Continuity of water supply which is still constrained overallr.

5) Continuity of water supply that is still constrained

\section{Research purposes}

The purpose of the study are:

1) Availability of existing water source data source in Pucang Gading area.

2) As a material to analyze any raw water resources available.

3) Determine the amount of drinking water needs that will be used by the community

4) Being a reference for the relevant government regulation on raw water supply system for drinking water

5) Provide knowledge to the public about the importance of maintaining the sustainability of water resources

\section{Methodology And Results}

\subsection{Clean Water Requirement Pucang Gading Housing}

The calculation of water demand begins with the calculation of population growth projection. The planning area is located in Pucang Gading Housing, Batursari Village, Mranggen District, Demak District.

The chosen projection method is using a geometric formula. When viewed from population growth, the population increase in Pucang Gading Housing area projected for 14 years with is as follows :

$$
P_{n}=P_{o}(1+\mathrm{r})^{n}
$$

$\mathrm{P}_{\mathrm{n}}=$ Population at the end of the $-\mathrm{n}$ year (people)

$\mathrm{P}_{\mathrm{o}}=$ Number of population in the year reviewed (people) $\mathrm{r}=$ Annual population growth rate $(\%)$

$\mathrm{n}=$ Number of years of projection then it can be calculated:

$$
\begin{aligned}
& P_{n}=P_{o}(1+\mathrm{r})^{n} \\
& P_{n}=44.257(1+0,2)^{1} \\
& P_{n}=44.346----->\text { Projection of } 2017 .
\end{aligned}
$$

then its growth will look like picture 1 .

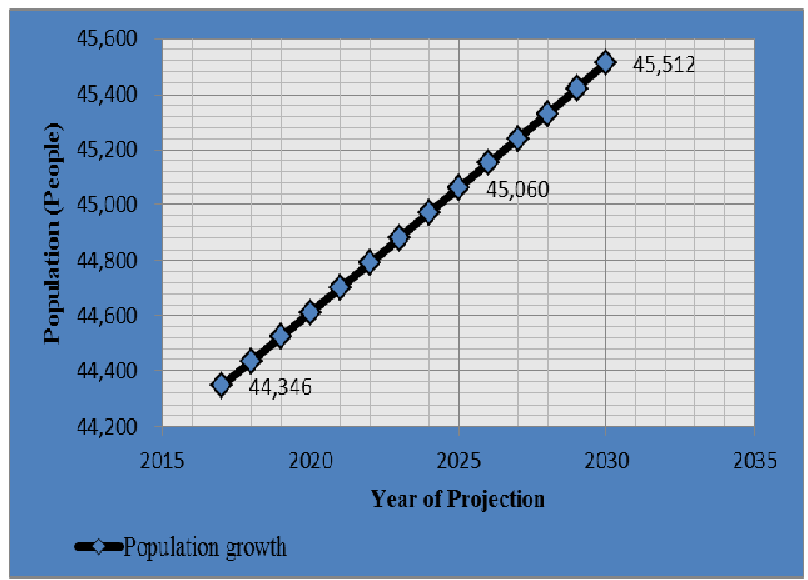

Figure 1. Projection of the resident of Pucang Gading

According from Figure 1 can be seen that the projected population growth in Pucang Gading Housing in 2017 reached 44,346 people, the year 2025 reached 45,060 people and in 2030 reached 45,512 inhabitants.

The projected amount of clean water demand in Pucang Housing is shown in Table 1.

Table 1. The Need for Clean Water in Pucang Gading Area

\begin{tabular}{c|ccc}
\hline Year & $\begin{array}{c}\text { Normal } \\
\text { (ltr/sec) }\end{array}$ & $\begin{array}{c}\text { Maximum Daily } \\
\text { Debit }(1,15) \\
(\text { ltr/sec) }\end{array}$ & $\begin{array}{c}\text { Clock } \\
\text { Discharge Peak } \\
(1,50)(\text { ltr } / \text { sec })\end{array}$ \\
\hline 2017 & 22.30 & 25.65 & 33.45 \\
2018 & 32.78 & 37.70 & 49.17 \\
2019 & 42.74 & 49.15 & 64.11 \\
2020 & 52.04 & 59.84 & 78.05 \\
2021 & 63.72 & 73.28 & 95.59 \\
2022 & 63.69 & 73.25 & 95.54 \\
2023 & 63.75 & 73.32 & 95.63 \\
2024 & 71.01 & 81.67 & 106.52 \\
2025 & 73.26 & 84.25 & 109.89 \\
2026 & 76.85 & 88.38 & 115.27 \\
2027 & 78.42 & 90.18 & 117.63 \\
2028 & 81.36 & 93.57 & 122.05 \\
2029 & 77.51 & 89.14 & 116.27 \\
2030 & 78.57 & 90.36 & 117.86 \\
\hline \multicolumn{2}{|c}{ Source: Calculation Result.2017 }
\end{tabular}

Source: Calculation Result, 2017

Domestic water demand is greatly affected by the amount of water per person per day which includes bathing, washing, personal hygiene and other domestic necessities. The need for domestic purposes is influenced by two factors: population and domestic water usage levels. 
The target mandated in the National Medium-Term Development Plan (RPJMN) 2015-2019 is $100 \%$ secure access to drinking water in 2019.

The projected water demand in Pucang Gading Housing area with average usage in 2017 reaches 22.30 liter/second, 2025 reaches 73,26 liter/second, and year 2030 reaches 78,571t / dt.

Projection of clean water demand for 2017-2030 is presented in Figure 2.

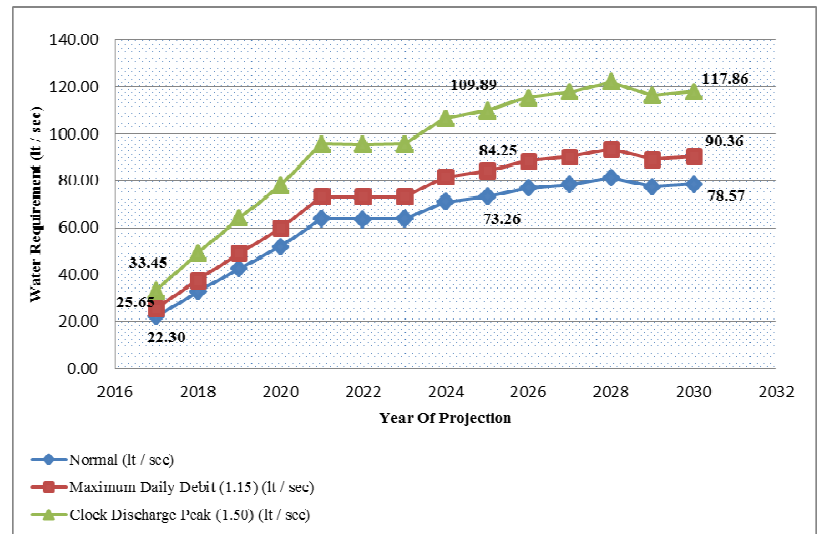

Figure 2. Projected Growth In Demand For Clean Water 2017-2030

\subsection{Raw Water Source Unit Mranggen}

The raw water source currently used is 57.49 liter/second which consists of six wells. The availability of raw water in Mranggen Sub-district is derived from the total capacity of potential and existing debits is shown in Table 2.

Table 2. Availability of Raw Water of Mranggen

\begin{tabular}{c|lrr}
\hline No & \multicolumn{1}{|c}{ Source } & \multicolumn{2}{c}{ Production } \\
\cline { 3 - 4 } & & $\mathbf{m}^{\mathbf{3}} / \mathbf{m o n t h}$ & liter/second \\
1 & Well 1/Terminal & $18,977.76$ & 7.09 \\
2 & Well 3/Argo & $20,688.41$ & 7.72 \\
3 & Well 4/ Santoso & $17,456.47$ & 6.52 \\
7 & Well 7/ Tlogo & $20,248.70$ & 7.56 \\
5 & Well 8 / Kantor & $28,792.80$ & 10.75 \\
6 & WTP / IPA Waru & $47,809.44$ & 17.85 \\
\multicolumn{3}{c}{ Source: Existing Data of PDAM Unit Mranggen, 2017}
\end{tabular}

The amount of clean water demand in Pucang Gading Housing with the amount of clean water supply available at the present time is shown in Figure 3 below:

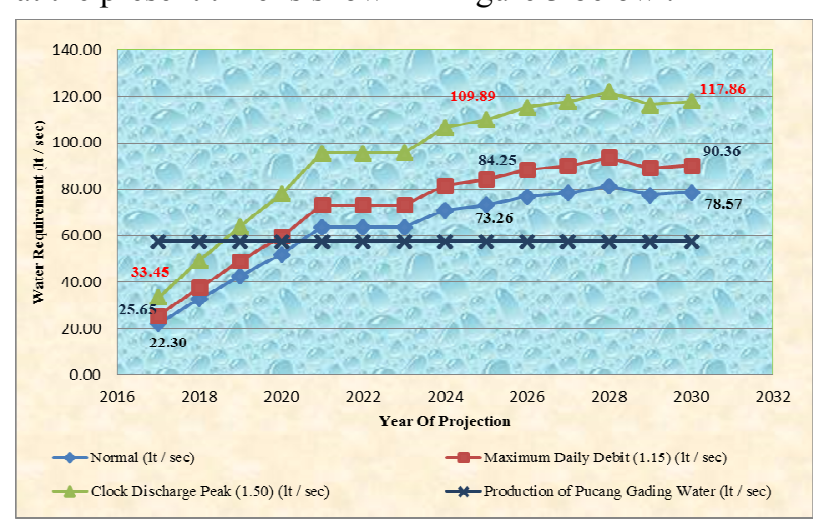

Figure 3. Clean Water Requirement Pucang Gading Housing

\subsection{SWOT Analysis of Pucang Gading Raw Water Needs}

From the results of the research on PDAM of Demak District to the Mranggen unit supported by the analysis of data and information obtained by other supporting documents on the management of the existing raw water source based on the National Medium-Term Development Plan 2015-2019 as previously described, then further through SWOT analysis tool will be described the analysis of internal and external environmental conditions which are the factors that affect the management of PDAM of Demak District Unit Mranggen Service so it can be known the management of raw water resources today. Raw water management will determine the direction of development into clean water in the future..

\subsubsection{Internal Scope}

On the internal scope then what happens is in PDAM Unit Mranggen yeng which within the internal scope in carrying out services in Pucang Gading Housing in particular can reduce or eliminate existing weaknesses and at the same time be a driver to achieve the goals of the company or unit. In the internal sphere is divided into corporate strengths and corporate weaknesses.

The internal scope that is the current strength for PDAM Unit Mranggen is the MDGs program mandated in the National Medium-Term Development Plan (RPJMN) 2015-2019 that is reaching $100 \%$ access to drinking water by the end of 2019, the percentage of service is also an important force for the company to continue to serve the needs of clean water, the addition of raw water sources which of course as a material to increase the production of clean water, the increasing number of customers every year, the income on sales of clean water continues to increase and the effort to improve the transmission and distribution network for the benefit of clean water services community or customer.

Internal scope for the company that become weakness at this time that is well or source of raw water which still not optimal to fulfill requirement of clean water, service level also still become obstacle for company, leakage level in transmission and distribution network still very high that reach $44,63 \%$ or about 14.63 liter/second, the production of clean water at this time is not maximal so it must find the source of raw water, the quality of raw water source can not be utilized as drinking water, the decrease of discharge in production and dristribution, and reservoir capacity which is still not sufficient accommodate raw water sources from water sources.

The calculation of value and internal factors are listed in table 3 below :

Table 3. The calculation of quality and internal factors

\begin{tabular}{|c|c|c|c|c|}
\hline No & Internal Factors & Value & Rating & Score \\
\hline$\overline{\mathrm{A}}$ & Strenght & & & \\
\hline 1 & $\begin{array}{l}\text { RPJMN 2015- } \\
2019\end{array}$ & 0,05 & 2 & 0,10 \\
\hline 2 & $\begin{array}{l}\text { Percentage of } \\
\text { Services }\end{array}$ & 0,06 & 3 & 0,27 \\
\hline
\end{tabular}




\begin{tabular}{|c|c|c|c|c|}
\hline No & Internal Factors & Value & Rating & Score \\
\hline 3 & $\begin{array}{l}\text { Addition of Raw } \\
\text { Water Source }\end{array}$ & 0,09 & 2 & 0,18 \\
\hline 4 & $\begin{array}{l}\text { Income Level } \\
\text { Increases }\end{array}$ & 0,06 & 3 & 0,36 \\
\hline 5 & $\begin{array}{l}\text { Number of } \\
\text { Customers Rising }\end{array}$ & 0,07 & 3 & 0,27 \\
\hline 6 & Sales increase & 0,12 & 3 & 0,27 \\
\hline B & $\begin{array}{l}\text { Efforts to Improve } \\
\text { Distribution and } \\
\text { Transmission } \\
\text { Network } \\
\text { Weakness }\end{array}$ & 0,06 & 3 & 0,18 \\
\hline 1 & $\begin{array}{l}\text { Deep Well Not } \\
\text { Optimal }\end{array}$ & 0,08 & 2 & 0,20 \\
\hline 2 & Leakage Level & 0,09 & 3 & 0,27 \\
\hline 3 & $\begin{array}{l}\text { Raw Water } \\
\text { Production }\end{array}$ & 0,06 & 2 & 0,14 \\
\hline 4 & $\begin{array}{l}\text { Decrease of Water } \\
\text { Debit }\end{array}$ & 0,05 & 2 & 0,20 \\
\hline 5 & $\begin{array}{l}\text { No Maximum } \\
\text { Service }\end{array}$ & 0,08 & 3 & 0,24 \\
\hline 6 & $\begin{array}{l}\text { Existing Reservoir } \\
\text { Capacity }\end{array}$ & 0,05 & 2 & 0,10 \\
\hline 7 & $\begin{array}{l}\text { The Quality of } \\
\text { Raw Water Source } \\
\text { Can Not Be } \\
\text { Utilized As } \\
\text { Drinking Water }\end{array}$ & 0,08 & 2 & 0,16 \\
\hline & Total & 1,00 & & 2,62 \\
\hline
\end{tabular}

Source: Calculation Result, 2017

The main weakness of a regional water supply company (PDAM) Demak unit Mranggen is reservoir capacity with score 0,10 , raw water production on transmission and distribution pipelines with score 0,14 . The results of PDAM Demak unit Mranggen during this time is to keep trying to reduce the leakage level that exist in transmission and distribution pipeline network. Another weakness that occurs in PDAM Demak unit Mranggen is the source of raw water in not optimal and the decrease of water flow each get score 0,20 , and for quality of raw water source can not be used as drinking water get score 0,16 . For score 0,24 is not maximal service and leakage rate get score 0,27 .

Overall, the total score score of six strengths and six weaknesses of the IFE matrix is 2.62. Thus, the company's internal condition is above the average value of 2.50. Based on the total value of quality, it can be concluded that the PDAM Demak unit Mranggen is in a strong position in harnessing the power possessed and sufficient to overcome the weakness.

\subsubsection{External Scope}

The external scope of opportunity is the level of consumption of clean water every year increased quite high, the number of population growth tends to increase rapid checks between the year 2017 amounted to 44,346 inhabitants and in 2030 amounted to 45,512 people with $0.2 \%$ growth rate, the level of demand for clean water which the community uses is also increasing, and the awareness level of the community to use clean water from the PDAM is progressing.

The external scope that threatens PDAMs is the widespread use of private wells by some housing communities, the declining level of service leads to lower levels of trust in PDAMs, reduced reforestation areas around raw water sources resulting in lower production of clean water, damage to transmission pipelines and distribution due to natural disasters and excavations carried out by irresponsible third parties, the easy licensing of private wells, the reform era that the community is very strong to seek profit around the location of raw water sources, and the geographic location of the very low water source becomes a possible factor minimal service to deliver water to customers

The calculation of value and external factors is shown in Table 4 below :

Table 4. Value calculation and External Strategic Factors

\begin{tabular}{|c|c|c|c|c|}
\hline No & External Factors & Value & Rating & Score \\
\hline $\mathrm{A}$ & Opportunity & & & \\
\hline 1 & $\begin{array}{l}\text { Water } \\
\text { Consumption } \\
\text { Level }\end{array}$ & 0,12 & 3 & 0,36 \\
\hline 2 & $\begin{array}{l}\text { Population } \\
\text { Growth Rate }\end{array}$ & 0,09 & 3 & 0,27 \\
\hline 3 & $\begin{array}{l}\text { Needs of Clean } \\
\text { Water }\end{array}$ & 0,08 & 3 & 0,24 \\
\hline 4 & $\begin{array}{l}\text { Community } \\
\text { Awareness Level }\end{array}$ & 0,07 & 3 & 0,21 \\
\hline 5 & $\begin{array}{l}\text { Market Potential } \\
\text { is Good }\end{array}$ & 0,09 & 3 & 0,27 \\
\hline 6 & $\begin{array}{l}\text { Gaining Capital } \\
\text { From Outside }\end{array}$ & 0,05 & 2 & 0,1 \\
\hline B & Threat & & & \\
\hline 1 & $\begin{array}{l}\text { Use of the Private } \\
\text { Well }\end{array}$ & 0,10 & 2 & 0,20 \\
\hline 2 & Service & 0,07 & 3 & 0,21 \\
\hline 3 & Greening Areas & 0,07 & 2 & 0,14 \\
\hline 4 & $\begin{array}{l}\text { Transmission } \\
\text { Damage }\end{array}$ & 0,10 & 2 & 0,20 \\
\hline 5 & Permissions & 0,09 & 3 & 0,27 \\
\hline 6 & Reform Era & 0,08 & 3 & 0,24 \\
\hline & Total & 1,0 & & 2,64 \\
\hline
\end{tabular}

Source: Calculation Result, 2017

Based on the EFE matrix table, the main opportunity of PDAM Demak unit Mranggen is the high level of clean water consumption with score 0,36 . The highest score shows that support from the community is an opportunity that should be utilized for PDAM unit Mranggen, because without support and participation from society can hamper performance level of PDAM Demak unit Mranggen own.

A score of 0.27 is the population growth rate and the market potential is quite good indicating the rate of water use is increasing. The increasing demand for clean water with a score of 0.24 becomes capital for PDAM Demak unit Mranggen to keep increasing the level of clean water service to the customer. While the score of 0.21 for the level of public awareness of the use of clean water provided by PDAM Demak unit Mranggen become its own motivation for PDAM unit Mranggen. Last is the opportunity to get capital from outsiders with a score of 0.1 .

The main threat factor for PDAM Demak unit Mranggen is greening area around the water source with score 0,14 . With a score of 0.20 each is the use of private wells and transmission network damage. As for the threat of 
service level with a score of 0.21 , this indicates that the level of service PDAM Demak unit Mranggen still relatively low. Score 0.24 is for the reform era, this hala is due to every change of leader will have an impact on policy policy that has been built by the company and will result in less good impact for the company's own performance. And last is a score of 0.27 , which is a threat to licensing, indicating that many people use land that is considered as a field to find their own water source or other work so that the production of clean water becomes reduced.

Overall, the total score of six opportunities and six threats on the EFE matrix is 2.64 or above the average value of 2.50 . Based on the total value of quality can be concluded, if the PDAM Demak unit Mranggen able to respond to the external environment of the company by exploiting opportunities owned by the company to face the threat.

\subsubsection{Matriks IE}

The IE matrix is based on the results of internal factor analysis and external factors combined from the IFE matrix and the EFE matrix. IE Matrix PDAM Demak Mranggen unit can be seen in picture 3 below:

IFE TOTAL SCORE

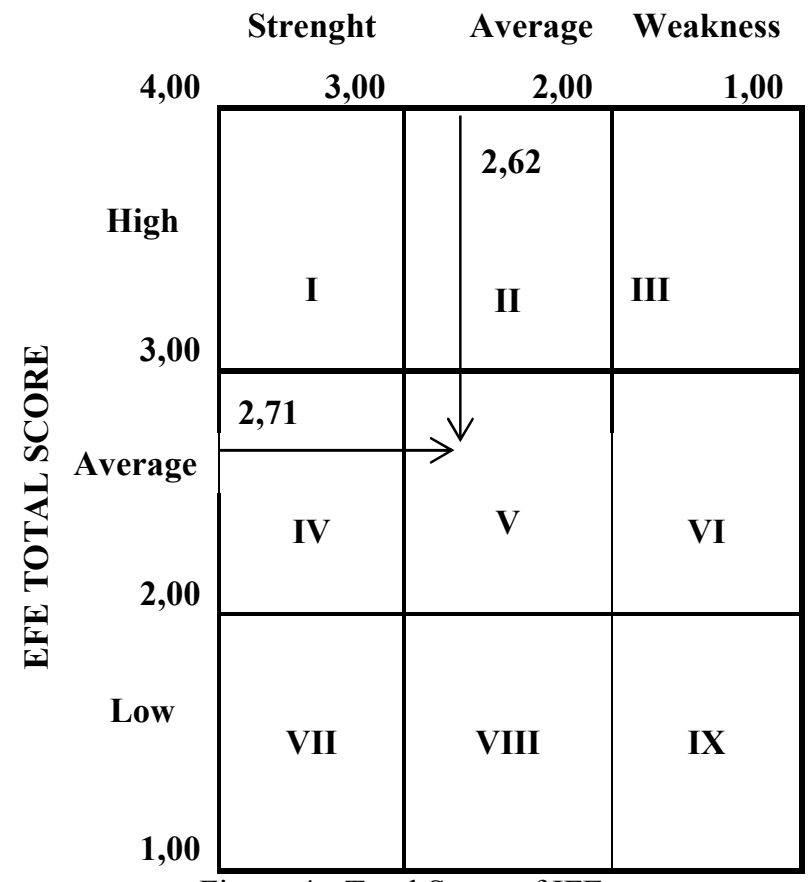

Figure 4. Total Score of IFE

The result of internal factor analysis using IFE matrix obtained the total score score of 2.62. While the result of the analysis of external factors using EFE matrix obtained the total score of 2.71. Based on the total scores of the IFE and EFE matrices it places the PDAM Demak unit Mranggen on cell V in IE matrix. Strategies that can be taken on the position of the cell is the strategy of maintaining and maintaining (Hold and Maintain). The best strategy that can be done is a strategy to improve services and development of clean water network.

From each strategy can be described or derived various development programs that support the development of
PDAM unit Mranggen. The SWAT matrix of PDAM Demak unit Mranggen is shown in table 5 below:

Table 5. Tabel Matriks IFE dan EFE

\begin{tabular}{|c|c|c|}
\hline $\begin{array}{l}\text { External } \\
\text { Factors }\end{array}$ & $\begin{array}{l}\text { Strenght (S) } \\
\text { 1. RPJMN } \\
\text { 2015-2019 } \\
\text { 2. Rate of } \\
\text { service } \\
\text { 3. Source of } \\
\text { raw water } \\
\text { 4. Income } \\
\text { level } \\
\text { increases } \\
\text { 5. Subscribers } \\
\text { increasing } \\
\text { 6. Sales } \\
\text { increase }\end{array}$ & $\begin{array}{l}\text { Weakness } \\
\text { (W) } \\
\text { 1. Source of } \\
\text { raw water } \\
\text { 2. Leakage } \\
\text { rate } \\
\text { 3. Raw water } \\
\text { production } \\
\text { 4. Decrease } \\
\text { in } \\
\text { discharge } \\
\text { 5. Lack of } \\
\text { capital } \\
\text { 6. Service } \\
\text { coverage } \\
\text { is low }\end{array}$ \\
\hline $\begin{array}{l}\begin{array}{c}\text { Opportunity } \\
\text { (O) }\end{array} \\
\text { 1. Amount o } \\
\text { water } \\
\text { consumption } \\
\text { 2. Population } \\
\text { growth rate } \\
\text { 3. Needs clean } \\
\text { water } \\
\text { 4. Level of } \\
\text { public } \\
\text { awareness } \\
\text { 5. The market } \\
\text { potential is } \\
\text { quite good } \\
\text { 6. Getting } \\
\text { capital from } \\
\text { outside }\end{array}$ & $\begin{array}{l}\text { Strategy SO } \\
\text { 1. RPJMN } \\
\text { 2015-2019 } \\
\text { as a } \\
\text { reference } \\
\text { level of } \\
\text { water needs } \\
\text { 2. The level of } \\
\text { public } \\
\text { awareness } \\
\text { of the } \\
\text { importance } \\
\text { of raw } \\
\text { water }\end{array}$ & $\begin{array}{l}\text { Strategy WO } \\
\text { 1. Lack of } \\
\text { capital } \\
\text { decrease } \\
\text { level of } \\
\text { PDAM } \\
\text { 2. The rate } \\
\text { of } \\
\text { population } \\
\text { growth } \\
\text { will } \\
\text { increase } \\
\text { the need } \\
\text { for clean } \\
\text { water }\end{array}$ \\
\hline $\begin{array}{l}\text { Threat (T) } \\
\text { 1. Use of } \\
\text { private wells } \\
\text { 2. Service } \\
\text { 3. Reforestation } \\
\text { area } \\
\text { 4. Damage of } \\
\text { transmission } \\
\text { due to nature } \\
\text { 5. Permissions } \\
\text { 6. Reformation } \\
\text { Era }\end{array}$ & $\begin{array}{l}\text { Strategy ST } \\
\text { 1. Control over } \\
\text { the } \\
\text { preservation } \\
\text { of nature } \\
\text { 2. Providing } \\
\text { services to } \\
\text { the } \\
\text { community } \\
\text { according to } \\
\text { PDAM } \\
\text { program }\end{array}$ & $\begin{array}{l}\text { Strategy WT } \\
\text { 1. Lowering } \\
\text { leakage } \\
\text { rate and } \\
\text { damage to } \\
\text { transmissi } \\
\text { on pipes } \\
\text { 2. Lower the } \\
\text { use of } \\
\text { private } \\
\text { wells }\end{array}$ \\
\hline
\end{tabular}

Based on the above strategy matrix, then alternative operational strategies that can be done for PDAM Demak unit development Mranggen is as follows.

1. RPJMN 2015-2019 program as a reference level of water needs.

2. The level of public awareness of the importance of raw water resources. 
3. Lack of capital decreased level of PDAM performance of Mranggen unit.

4. The rate of population growth will increase the need for clean water.

5. Control of nature conservation.

6. Providing services to the community according to PDAM program.

7. Lowered leakage level and damage to transmission pipes.

8. Reduced level of use of private wells.

\section{Conclusion}

Based on the results and discussions that have been described above before, then got some conclusions as follows:

1) Population is increasing every year, by 2030 the population is 45,512 people.

2) The total need of clean water of Pucang Gading housing area in 2030 is 78,57 liter / second with service percentage reach $100 \%$.

3) Fluctuation of water needs of Pucang Gading service area are:

a. The average need for Pucang Gading service area is 78.57 liters / second.

b. The need for maximum day debit (1.15) is 90.36 liters / second

c. The peak hour requirement is 117.86 liters / second

4) Demand for clean water of Pucang Gading area is getting bigger while the raw water source production capacity is only 70 liters / second, so for the next few years the PDAM should try to add new network to continue to supply clean water needs.

5) The result of SWOT analysis of PDAM unit identification of Mranggen unit is as follows:

a. The result of identification of internal environment which is the strength of PDAM Demak unit Mranggen is RPJMN 2015-2019, percentage of service, utilization of raw water source, income level increase, customer number increase and sales of raw water increases. Weaknesses are raw water source capacity, leakage rate, raw water production, decrease of discharge, lack of capital and service coverage. b. The result of the identification of the external environment which is an opportunity for PDAM Demak unit Mranggen is the rate of water consumption increase, the rate of population growth, the need of clean water, the level of public awareness, the market potential is good enough and get the capital from outside. The threat faced by the company is the use of private wells, services, green areas, natural transmission damage, licensing and reform era..

6) Based on the SWOT matrix analysis a commonly used strategy is maintaining and maintaining strategies or unchanging strategies. Strategy undertaken, namely by improving services and development of clean water network. An alternative strategy for developing production and distribution levels is the addition of water transmission and distribution networks, the maintenance of green areas to maintain the preservation of raw water resources.

\section{References}

1. Arya Rezagama dan Arwin (2015), Supply And Demand Scenario In Drinking Water Supply Semarang City On Achieving MDGs In 2015 Until 2030, Journal of Geography Media Information and Geograph Science and Profession.

2. Central Bureau of Statistics of Demak Regency, Mranggen Sub District In Figures 2017.

3. Dody Kurniawan (2008), inal Task Fulfillment of Clean Water Needs for Communities At Perumnas Pucang Gading, Department of Regional Planning And City Faculty of Engineering Diponegoro University of Semarang.

4. Clean Water, Regional Water Company of Demak Regency Year 2016.

5. Government Regulation No.121 of 2015 on the Management of Water Resources

6. Government Regulation of the Republic of Indonesia Number 122 Year 2015 on Water Supply System

7. Rangkuti (2009: 31), SWOT Analysis Techniques Dissecting Business Cases.

8. National Medium Term Development Plan (RPJMN) 2015-2019.

9. Robert J. Kodoatie, Roestam Sjarief. (2005), Integrated Water Resources Management Yogyakarta Andi Offset.

10. Tri Joko (2009), Raw Water Unit in Drinking Water Supply System.

11. Law of the Republic of Indonesia Number 7 Year 2004, Water Resources.. 